\title{
Atrial Natriuretic Peptide ${ }_{(31-67)}$ Inhibits $\mathrm{Na}^{+}$Transport in Rabbit Inner Medullary Collecting Duct Cells
}

\author{
Role of Prostaglandin $\mathrm{E}_{2}$
}

Mark E. Gunning, Hugh R. Brady, Godwin Otuechere, Barry M. Brenner, and Mark L. Zeidel

Departments of Medicine, Brigham and Women's and Brockton-West, Roxbury Veterans Administration Hospitals, Harvard Center for the Study of Kidney Diseases, Harvard Medical School, Boston, Massachusetts 02115

\begin{abstract}
Atrial natriuretic peptide $(\mathrm{ANP})_{(31-67)}$, a portion of the atrial peptide prohormone, circulates in humans, and its plasma level varies with atrial pressure. Like the more widely studied carboxy-terminal fragment $\mathrm{ANP}_{(99-126)}, \mathbf{A N P}_{(31-67)}$ stimulates natriuresis and diuresis. We examined the mechanism of this natriuresis by measuring the effects of $\mathrm{ANP}_{(31-67)}$ on $\mathrm{Na}^{+}$transport in cells of the rabbit inner medullary collecting duct (IMCD). $\operatorname{ANP}_{(31-67)}\left(10^{-8} \mathrm{M}\right)$ caused a $26 \pm 4 \%$ inhibition of oxygen consumption $\left(\mathrm{QO}_{2}\right)$; half-maximal inhibition occurred at $10^{-11} \mathrm{M}$, suggesting a physiologic effect. This effect was not additive with either ouabain or amiloride, suggesting that it reflected inhibition of $\mathrm{Na}^{+}$transport-dependent $\mathbf{Q O}_{2} . \mathbf{A N P}_{(31-67)}$ reduced the amphotericin-induced stimulation of $\mathrm{QO}_{2}$ consistent with inhibition by this peptide of the $\mathrm{Na}^{+}-\mathrm{K}^{+}$-ATPase. In addition, $\mathrm{ANP}_{(31-67)}$ reduced ouabain-sensitive ${ }^{86} \mathbf{R b}^{+}$uptake under $\mathrm{V}_{\max }$ conditions. Several lines of evidence indicated that $\mathbf{P G E}_{2}$, a known endogenous IMCD Na${ }^{+}-\mathrm{K}^{+}$-ATPase inhibitor, mediates pump inhibition by $\mathbf{A N P}_{(31-67)}$. Thus, $\mathbf{A N P}_{(31-67)}$ inhibits $\mathrm{Na}^{+}$ transport by inhibiting the $\mathrm{Na}^{+}-\mathrm{K}^{+}$-ATPase of IMCD cells, an effect mediated by the generation of $\mathrm{PGE}_{2}$. (J. Clin. Invest. 1992. 89:1411-1417.) Key words: $\mathrm{Na}^{+}-\mathrm{K}^{+}$-ATPase $\bullet$ renal medulla $\bullet \mathrm{Na}^{+} \cdot$ Pro-ANP $\bullet$ atrial natriuretic peptide $\bullet$ collecting duct
\end{abstract}

\section{Introduction}

Early studies of the potent natriuretic and diuretic properties of atrial natriuretic peptides used a crude saline extract from homogenized atria which, when injected into assay rats provoked striking natriuresis, diuresis, and hypotension (1-3). Subsequent studies soon demonstrated that atria secrete a prohormone, atrial natriuretic peptide (ANP) $)_{(1-126)},{ }^{1}$ from which the carboxy-terminal 28 amino acid $\mathrm{ANP}_{(99-126)}$ is rapidly cleaved (4-6). Because the most readily identifiable circulating product of $\mathrm{ANP}_{(1-126)}$ was $\mathrm{ANP}_{(99-126)}$ (also known as $\mathrm{ANP}_{(1-28)}$, or sim-

Address correspondence and reprint requests to Dr. Mark L. Zeidel, Renal Section, Medical Service, West Roxbury D.V.A.M.C., 1400 VFW Parkway, West Roxbury, MA 01232.

Received for publication 23 April 1991 and in revised form 2 January 1992

1. Abbreviations used in this paper: ANP, atrial natriuretic peptide; GFR, glomerular filtration rate; HOWI, head-out water immersion; IBMX, isobutyl methyl xanthine; IMCD, inner medullary collecting duct; $\mathrm{QO}_{2}$, oxygen consumption.

The Journal of Clinical Investigation, Inc.

Volume 89, May 1992, 1411-1417 ply ANP), virtually all subsequent studies were directed towards defining the action of this carboxy-terminal fragment (4). Little attention was paid to the other product of cleavage, $\operatorname{ANP}_{(1-98)}$, and its derivative peptides. The original infusion studies with atrial extracts presumably involved $\mathrm{ANP}_{(1-98)}$ and fragments thereof, as well as $\mathrm{ANP}_{(99-126)}$, and, subsequently, Kangawa et al. showed that infusion of intact $\mathrm{ANP}_{(1-98)}$ had natriuretic effect $(5,7)$.

More recent evidence suggests that a fragment of $\mathrm{ANP}_{(1-98)}$, $\mathrm{ANP}_{(31-67)}$, also circulates in plasma $(8,9)$. Antibodies raised against synthetic $\mathrm{ANP}_{(31-67)}$ and specific for this peptide identified a circulating peptide of molecular weight similar to that of synthetic $\operatorname{ANP}_{(31-67)}$ (molecular mass $\sim 4,000 \mathrm{D}$ ). This circulating peptide coeluted with synthetic $\mathrm{ANP}_{(31-67)}$ on reverse phase HPLC $(8,9)$. Furthermore, this same peptide circulates at a concentration greater than ten times that of $\mathrm{ANP}_{(99-126)}$, and, as with $\mathrm{ANP}_{(99-126)}$, the concentration of the peptide increases in the setting of increased right atrial pressure (e.g., head-out water immersion [HOWI] or congestive heart failure) $(9,10)$. Finally, infusion of synthetic $\operatorname{ANP}_{(31-67)}$ into rats proves it to be natriuretic and diuretic, similar in potency to $\operatorname{ANP}_{(99-126)}$ (11). Since the natriuretic effect of $\mathrm{ANP}_{(31-67)}$ was not accompanied by any change in glomerular filtration rate (GFR), the peptide, like $\mathrm{ANP}_{(99-126)}$, must have a tubule site of action (11). Thus, there is strong evidence that atrial regulation of renal $\mathrm{Na}^{+}$excretion may not be mediated solely through the carboxy-terminal $\mathrm{ANP}_{(99-126)}$ fragment of the $\mathrm{ANP}_{(1-126)}$ molecule, but also via the product of the cleaved $\mathrm{ANP}_{(1-98)}$, namely $\mathrm{ANP}_{(31-67) \text {. }}$

We and others have previously shown that $\mathrm{ANP}_{(99-126)}$ binds to specific cell-surface guanylate cyclase-linked receptors, leading to increased cGMP generation, which in turn reduces the open time of luminal plasma membrane sodium channels (1215). Inhibition of these $\mathrm{Na}^{+}$channels is believed to cause reduced $\mathrm{Na}^{+}$reabsorption, leading to natriuresis $(3,12,15)$. We have, therefore, now examined the effect of $\mathrm{ANP}_{(31-67)}$ on $\mathrm{Na}^{+}$ transport in these cells, and determined the mechanism by which this ANP fragment acts on the inner medullary collecting duct (IMCD) cell to exert its natriuretic effect.

\section{Methods}

Tissue preparation. Fresh suspensions of IMCD cells were prepared as described previously $(13,16)$. Anesthetized rabbits were decapitated and exsanguinated, and the kidneys were removed and perfused via the renal artery, with a solution consisting of nonbicarbonate Ringer (containing $\mathrm{NaCl}, 130 \mathrm{mM} ; \mathrm{KCl}, 5 \mathrm{mM} ; \mathrm{CaCl}_{2}, 1 \mathrm{mM} ; \mathrm{MgSO}_{4}, 1 \mathrm{mM}$; $\mathrm{NaH}_{2} \mathrm{PO}_{4}, 1 \mathrm{mM}$; Tris-Hepes, $10 \mathrm{mM}$; $\mathrm{pH}$ 7.4) diluted 1:1 with Joklik's medium containing $10 \%$ fetal bovine serum (Joklik's). The kidneys were perfused with iced medium until the effluent was clear of blood, and the inner medullae were excised and placed in Joklik's me- 
dium. Medullas were minced and subjected to dispersion in $0.2 \%$ collagenase for $90 \mathrm{~min}$ at $37^{\circ} \mathrm{C}$ in a shaking water bath. During the incubation, the suspension was agitated and aspirated intermittently, using a Pasteur pipette to break up clumps of cells, tubule fragments, and connective tissue. The resulting suspension of inner medullary cells was layered on $16 \%$ Ficoll in nonbicarbonate Ringer's and centrifuged at $4^{\circ} \mathrm{C}$ at $2,300 \mathrm{~g}$ for $45 \mathrm{~min}$. IMCD cells were harvested from the interface between the Joklik's medium and the Ficoll. Cells were used within $2 \mathrm{~h}$ of preparation, and were kept on ice until study. Homogeneity of the preparation was assessed by phase contrast microscopy. There were no smooth muscle or endothelial cells visible in the preparations. Cell viability was greater than $90 \%$, using trypan blue exclusion. IMCD cells prepared in this manner exhibit high glycolytic capacity $(13,17)$, inhibition of $\mathrm{Na}^{+}$transport with amiloride $(14,16)$, increased cAMP accumulation in response to arginine vasopressin (AVP) (13), and increased cGMP accumulation in response to $\operatorname{ANP}_{(99-126)}(13)$, all properties attributed to this segment in vivo.

Oxygen consumption $\left(Q_{2}\right)$. $\mathrm{QO}_{2}$ was measured as described previously $(18,19)$, in sealed continuously stirred water-jacketed $400-\mu$ l glass chambers at $37^{\circ} \mathrm{C}$. Nonbicarbonate Ringer's medium contained $10 \mathrm{mM}$ pyruvate and $2 \mathrm{mM}$ acetate, $\mathrm{pH}$ 7.4. After a control period to establish a stable baseline, additions of agents were made in volumes of $<1 \%$ of the volume of the chamber to eliminate potential dilutional problems; addition of DMSO or incubation buffer did not alter $\mathrm{QO}_{2}$. The rate of $\mathrm{QO}_{2}$ was calculated from the slope of the recorded line by measuring its angle against the baseline and calculating its tangent. When the measurement of $\mathrm{QO}_{2}$ was ended, an aliquot of the cell suspension was removed and its wet weight was determined as described (18, 19). Results are expressed as millimoles of $\mathrm{O}_{2}$ consumed per gram wet weight.

${ }^{86} \mathrm{Rb}^{+}$uptakes. ${ }^{86} \mathrm{Rb}^{+}$uptakes were performed in cells preincubated for 60 min in $\mathrm{K}^{+}$-free (substitution of $\mathrm{NaCl}$ for $\mathrm{KCl}$, on a mole for mole basis) nonbicarbonate Ringer's medium with $5 \mathrm{mM}$ glucose as sole substrate $(17,18)$. At the end of the incubation, cells were treated for 5 min with peptide or vehicle. Uptakes were then initiated by the addition of ${ }^{86} \mathrm{Rb}^{+}(0.7 \mu \mathrm{Ci})$ in $\mathrm{KCl}$ (final $\mathrm{K}^{+}$concentration, $5 \mathrm{mM}$ ), and at the indicated times, $60-\mu l$ aliquots of the cell suspension were placed in $600 \mu$ l of a stop solution, and the cells were pelleted through oil as described $(17,18,20)$. Specific activity of ${ }^{86} \mathrm{Rb}^{+}$was determined by dispersing the pellet in $6 \%$ perchloric acid overnight, neutralizing the $\mathrm{pH}$, and counting in a liquid scintillation counter in Aquasol. Uptakes were performed with and without the indicated peptides in the presence and absence of ouabain. The uptake in the presence of ouabain ( $<30 \%$ of total uptake) was subtracted from that obtained in the absence of ouabain to give the ouabain-sensitive uptake; at no time point did the peptides alter the ouabain-insensitive uptake.

$P G E_{2}$ assay. IMCD cells were preincubated for $30 \mathrm{~min}$ at $37^{\circ} \mathrm{C}$ in nonbicarbonate Ringer with $5 \mathrm{mM}$ glucose. The suspension was sampled to provide basal $\mathrm{PGE}_{2}$ content, and either peptide or vehicle was added. After $5 \mathrm{~min}$ incubation at $37^{\circ} \mathrm{C}$, the reaction was stopped. $\mathrm{PGE}_{2}$ was extracted from all samples by methanol-ethanol extraction. $2 \mathrm{vol}$ of ice-cold ethanol was added to each sample, and the mixture allowed to stand at $4^{\circ} \mathrm{C}$ for $60 \mathrm{~min}$. The mixture was centrifuged at $2,000 \mathrm{~g}$ for $10 \mathrm{~min}$, and the supernatant was retained. The pellet was resuspended in two volumes of methanol, allowed to stand, and centrifuged as described above. The supernatants were pooled, dried under $\mathrm{N}_{2}$, and assayed for $\mathrm{PGE}_{2}$, using a commercial radioimmunoassay kit.

cGMP accumulation studies. IMCD cells were incubated at $37^{\circ} \mathrm{C}$ for $10 \mathrm{~min}$ before a further preincubation with $1 \mathrm{mM}$ isobutyl methyl xanthine (IBMX) for $2 \mathrm{~min}$ in preparation for measurement of cGMP accumulation. cGMP accumulation was measured in the preequilibrated cells over a 2-min incubation in the presence or absence of added peptide. After 2 min, the cells were precipitated with 12\% TCA. The TCA was extracted four times with $10 \mathrm{vol}$ of water-saturated ether before assay of cGMP $(13,20)$.

Materials. ${ }^{86} \mathrm{Rb}^{+}$, assay kits for determination of $\mathrm{PGE}_{2}$, and Aquasol were obtained from New England Nuclear, Boston, MA. Dioc- tyllphthallate and silicon oil were obtained from Aldrich Chem. Co., Milwaukee, WI. Collagenase was obtained from Worthington Biochemical Corp., Freehold, NJ. Joklik's Minimal Essential Medium was obtained from Gibco Laboratories, Grand Island, NY, and Ficoll was obtained from Pharmacia Fine Chemicals, Piscataway, NJ. Protein assay kits were obtained from Bio-Rad Chemical Division, Richmond, CA. cGMP radioimmunoassay kits were purchased from Biomed. Technols., Stoughton, MA. Natriuretic peptides ${\left(A_{N P}\right.}_{(31-67)}$ and ANP $\left._{(99-126)}\right)$ were obtained from Peninsula Laboratories Inc., Belmont, CA. All other reagents were obtained from Sigma Chemical Co., St. Louis, MO, and were of analytical grade.

Statistics. In all figures, a single $n$ represents the mean of determinations performed on a single cell preparation. Unless specified otherwise, experimental results are given for the mean \pm SE for four to eight separate cell preparations. Where appropriate, results of different groups are compared using unpaired or paired $t$ tests as indicated; $P$ $<0.05$ was deemed significant.

\section{Results}

To determine whether $\mathrm{ANP}_{(31-67)}$ altered $\mathrm{Na}^{+}$transport in IMCD cells, the effect of this peptide on $\mathrm{QO}_{2}$ was examined. Basal rates of $\mathrm{QO}_{2}$ were $0.31 \pm 0.04 \mu \mathrm{mol} / \mathrm{min}$ per g wet wt ( $n$ $=11$ ), a value similar to previous results $(13,16-18)$. As shown in the upper panel of Fig. 1, the addition of vehicle to the incubated cells caused no discernible change in the rate of oxygen consumption, whereas addition of $10^{-8} \mathrm{M} \mathrm{ANP}_{(31-67)}$ reduced $\mathrm{QO}_{2}$ on average by $26 \%$. As shown in the lower panel of Fig. 1, inhibition of $\mathrm{QO}_{2}$ was a function of increasing $\mathrm{ANP}_{(31-67)}$ concentration, and this inhibitory effect was maximal at about $100 \mathrm{pM}$. Half-maximal inhibition of $\mathrm{QO}_{2}$ occurred at $\sim 10$ $\mathrm{pM}$, a value similar to that at which this peptide is thought to circulate in human plasma $(9,10)$.

Inhibition of $\mathrm{QO}_{2}$ may be caused by a reduction in $\mathrm{Na}^{+}$ transport, reducing the demands of the $\mathrm{Na}^{+}-\mathrm{K}^{+}$-ATPase for metabolic energy, or by direct inhibition of mitochondrial $\mathrm{O}_{2}$ consumption. To determine whether the effect on $\mathrm{QO}_{2}$ was due to inhibition of $\mathrm{Na}^{+}$transport, the effect of $\mathrm{ANP}_{(31-67)}$ on $\mathrm{QO}_{2}$ was measured in the presence or absence of either the

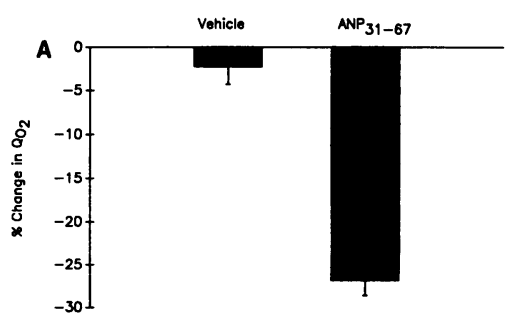

Figure 1. Effect of $\mathrm{ANP}_{31-67}$ on IMCD oxygen consumption $\left(\mathrm{QO}_{2}\right) .(A)$ After a stable basal rate of $\mathrm{QO}_{2}$ was obtained, IMCD cells were exposed to $10^{-8}$ M ANP ${ }_{31-67}$ or its vehicle (nonbicarbonate Ringer's), and the effects on $\mathrm{QO}_{2}$ determined. Basal $\mathrm{QO}_{2}$ in these preparations was

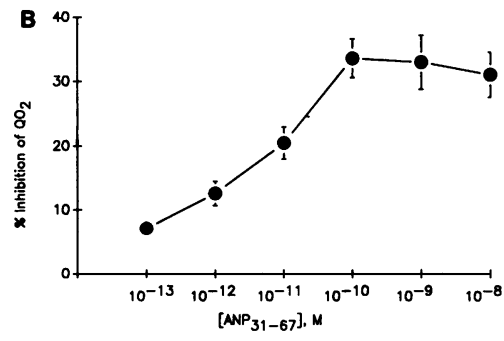
$0.31 \pm 0.04 \mu \mathrm{mol} / \mathrm{min}$ per $\mathrm{g}$ wet wt; after $\mathrm{ANP}_{31-67}$, this value averaged $0.21 \pm 0.03(P$ $<0.001$; paired $t$ test with $n=7$ pairs). (B) Effects of varying concentrations of $\mathrm{ANP}_{31-67}$ on $\mathrm{QO}_{2}$. 


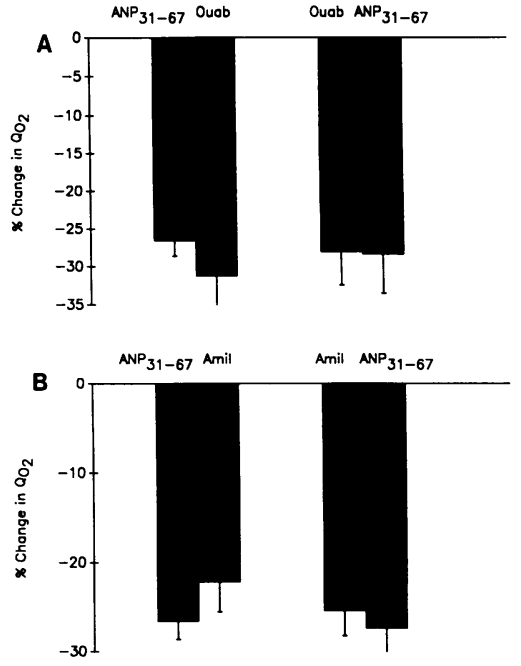

Figure 2. Interaction of $\mathrm{ANP}_{31-67}$ inhibition of $\mathrm{QO}_{2}$ with ouabain $(A)$ and amiloride $(B)$. After a stable baseline was obtained, cells were exposed to the agent indicated, followed by the second agent in the continued presence of the first agent.

$\mathrm{Na}^{+}-\mathrm{K}^{+}$-ATPase inhibitor ouabain, or the epithelial $\mathrm{Na}^{+}$channel inhibitor amiloride. As shown in Fig. $2 A$, the effect of addition of ouabain and $\mathrm{ANP}_{(31-67)}$ was nonadditive, regardless of the order of additions. Thus, once the $\mathrm{Na}^{+}-\mathrm{K}^{+}$-ATPase was inhibited maximally by ouabain, the inhibitory effect of $\mathrm{ANP}_{(31-67)}$ was no longer seen. Fig. $2 B$ demonstrates a similar set of experiments using the $\mathrm{Na}^{+}$channel inhibitor amiloride. Amiloride, by inhibiting $\mathrm{Na}^{+}$entry through the apical $\mathrm{Na}^{+}$ channel, reduces $\mathrm{Na}^{+}-\mathrm{K}^{+}$-ATPase activity and the consumption of metabolic energy by the pump. $\mathrm{QO}_{2}$ inhibition by $\mathrm{ANP}_{(31-67)}$ is not enhanced by amiloride, irrespective of the order of additions, whereas previous studies have shown that agents which directly reduce oxidative phosphorylation in IMCD cells, such as cyanide or glucose, give additive inhibition of $\mathrm{QO}_{2}$ with ouabain or amiloride $(16,17)$. In additional studies, $\mathrm{ANP}_{31-67}$ did not alter the rate of oxygen consumption obtained when mitochondrial oxygen metabolism was uncoupled with the mitochondrial poison, FCCP. These results indicate that $\mathrm{ANP}_{(31-67)}$ reduces $\mathrm{QO}_{2}$ not by direct inhibition of mitochondrial $\mathrm{O}_{2}$ consumption, but by reducing the demand for metabolic energy of the $\mathrm{Na}^{+}-\mathrm{K}^{+}$-ATPase.

A reduction of transcellular $\mathrm{Na}^{+}$transport could result from inhibition of $\mathrm{Na}^{+}$entry via $\mathrm{Na}^{+}$channels, or an inhibition of $\mathrm{Na}^{+}-\mathrm{K}^{+}$-ATPase itself. To determine which component of the $\mathrm{Na}^{+}$transporting mechanism was primarily inhibited by $\mathrm{ANP}_{(31-67)}$, we studied the effect of $\mathrm{ANP}_{(31-67)}$ on cells that were permeabilized to $\mathrm{Na}^{+}$with amphotericin $\mathrm{B}(10 \mu \mathrm{g} / \mathrm{ml})$. Shown in Fig. 3 is the effect on $\mathrm{QO}_{2}$ of amphotericin alone, or in combination with $\mathrm{ANP}_{(31-67)}(B)$ or $\mathrm{ANP}_{(99-126)}(A)$. Amphotericin alone caused a $25-35 \%$ stimulation of $\mathrm{QO}_{2}$ by allowing the entry of excess $\mathrm{Na}^{+}$into the cell and thus accelerating the activity of the $\mathrm{Na}^{+}-\mathrm{K}^{+}$-ATPase to $\mathrm{V}_{\max }$. In Fig. $3 \mathrm{~B}$ is shown the $\mathrm{ANP}_{(31-67)}$ inhibition of $\mathrm{QO}_{2}$ averaging $26 \%$. Although this inhibition is reversed by the subsequent addition of amphotericin, the overall result of this combination is a net stimulation of $\mathrm{QO}_{2}$ of only $7 \%$. Thus, the inhibitory effect of the peptide is seen in its ability to attenuate the stimulation usually seen with amphotericin. If the order of additions is reversed, amphotericin increases $\mathrm{QO}_{2}$ by $35 \%$ as expected, and the subsequent addition of $\mathrm{ANP}_{(31-67)}$ inhibits $66 \%$ of this stimulation. Thus, from these data we conclude that $\mathrm{ANP}_{(31-67)}$ has an inhibitory effect

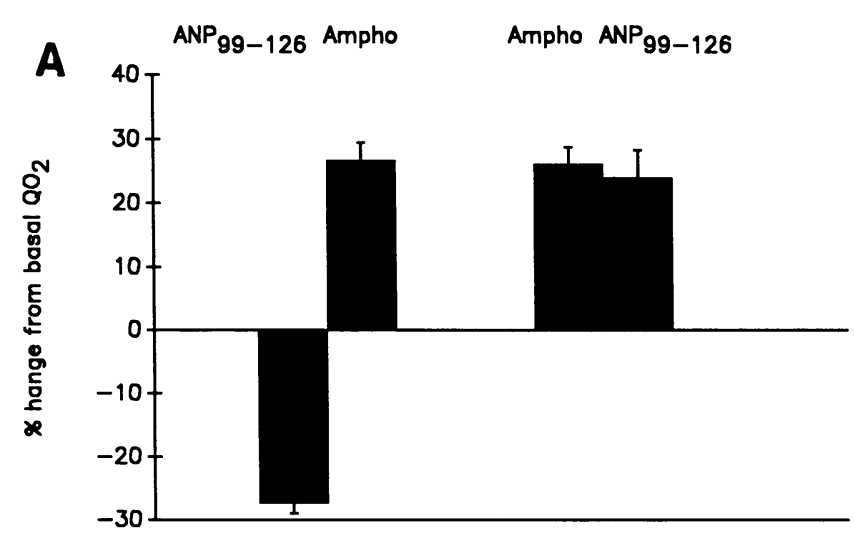

on the rate of pumping by the $\mathrm{Na}^{+}-\mathrm{K}^{+}$-ATPase. By way of comparison, Fig. $3 \mathrm{~A}$ demonstrates the interaction of $\mathrm{ANP}_{(99-126)}$ and amphotericin. Although $\mathrm{ANP}_{(99-126)}$ inhibits $\mathrm{QO}_{2}$ to a degree similar to that of $\mathrm{ANP}_{(31-67)}$, subsequent addition of amphotericin not only reverses this inhibition but also stimulates $\mathrm{QO}_{2}$ by $\sim 25 \%$, as would be expected from amphotericin alone, suggesting that the inhibition by $\mathrm{ANP}_{(99-126)}$ was not due to direct inhibition of the $\mathrm{Na}^{+}-\mathrm{K}^{+}$-ATPase. Furthermore, prior stimulation of $\mathrm{Na}^{+}-\mathrm{K}^{+}$-ATPase with amphotericin blocks the action of $\mathrm{ANP}_{(99-126)}$. Thus, $\mathrm{ANP}_{(31-67)}$ appears to inhibit the $\mathrm{Na}^{+}-\mathrm{K}^{+}$-ATPase, an effect entirely different than the $\mathrm{Na}^{+}$channel blocking effect of $\mathrm{ANP}_{(\text {(99-126) }}$.

To determine more directly whether $\mathrm{ANP}_{(31-67)}$ inhibits $\mathrm{Na}^{+}-\mathrm{K}^{+}$-ATPase, rates of ouabain-sensitive ${ }^{86} \mathrm{Rb}^{+}$uptake into IMCD cells were examined in the presence or absence of $\mathrm{ANP}_{(31-67)}$. To insure that any effects measured were not due to regulatory effects of $\mathrm{Na}^{+}$entry on the pump, $\mathrm{Na}^{+}-\mathrm{K}^{+}$-ATPase activity was maximally accelerated by preincubation of the cells in $\mathrm{K}^{+}$-free Ringer's followed by addition of isotope in the

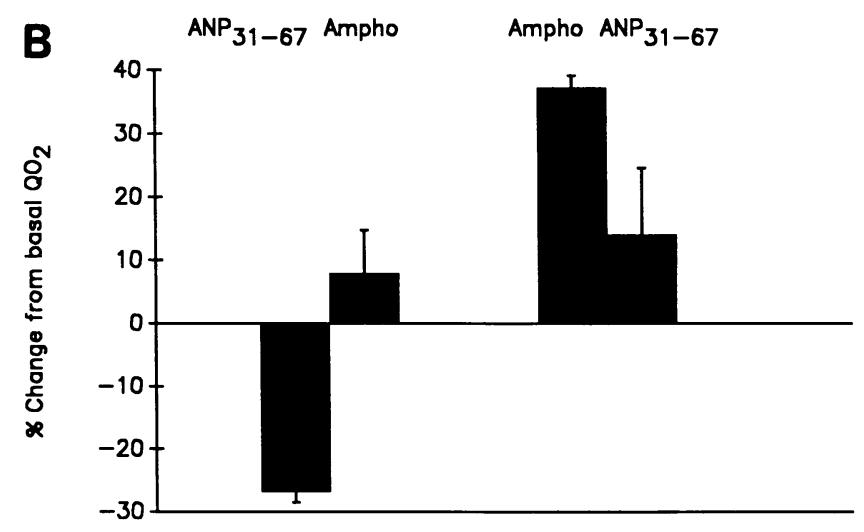

Figure 3. Interaction of $\mathrm{ANP}_{31-67}$ or $\mathrm{ANP}_{99-126}$ inhibition of $\mathrm{QO}_{2}$ with amphotericin $\mathrm{B}$. $(A)$ On the left, $\mathrm{ANP}_{99-126}$ was added, followed by amphotericin $\mathrm{B}$ in the continued presence of $\mathrm{ANP}_{99-126}$; on the right, the order of additions was reversed. $(B)$ On the left, $\mathrm{ANP}_{31-67}$ was added, followed by amphotericin $B$ in the continued presence of $\mathrm{ANP}_{31-67}$; on the right, the order of additions was reversed. $\mathrm{QO}_{2}$ after addition of ouabain averaged $0.38 \pm 0.06 \mu \mathrm{mol} / \mathrm{min}$ per $\mathrm{g}$ wet wt; if amphotericin was added after exposure of the cells to $\mathrm{ANP}_{31-67}, \mathrm{QO}_{2}$ averaged $0.23 \pm 0.05(P<0.005$; paired $t$ test comparing amphotericin first or after $\mathrm{ANP}_{31-67}$ in five paired experiments). Data for $A$ were taken from reference 16. 


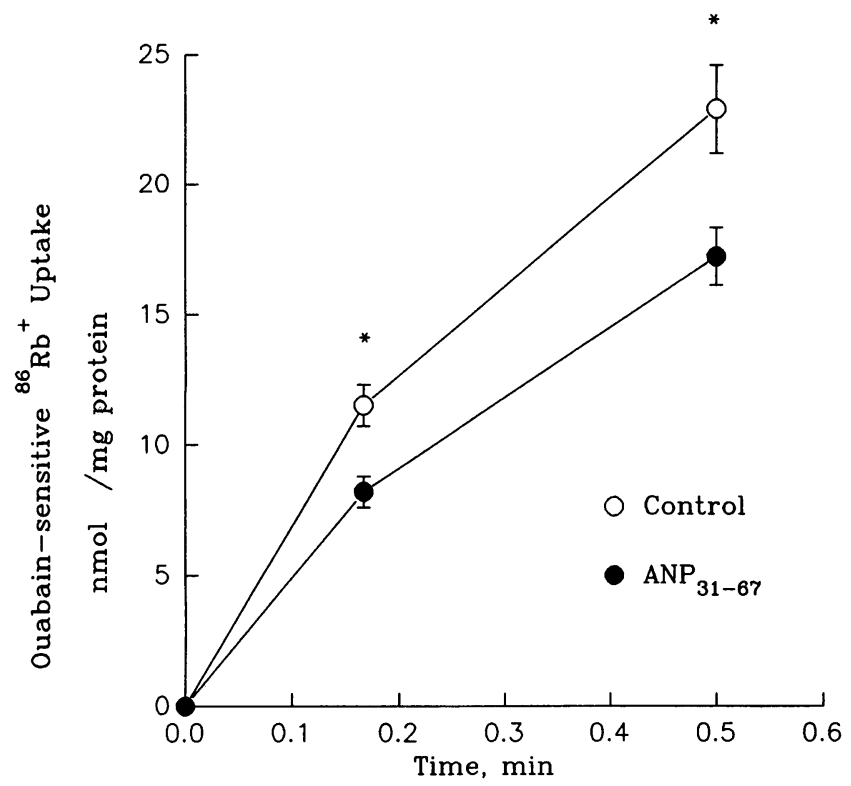

Figure 4. Effect of $\mathrm{ANP}_{31-67}$ on ouabain-sensitive ${ }^{86} \mathrm{Rb}^{+}$uptake. To deplete intracellular $\mathrm{K}^{+}$and increase intracellular $\mathrm{Na}^{+}$, cells were preincubated $60 \mathrm{~min}$ in $\mathrm{K}^{+}$-free nonbicarbonate Ringer at $37^{\circ} \mathrm{C}$. Uptakes were initiated by abrupt addition of ${ }^{86} \mathrm{Rb}^{+}$and sufficient $\mathrm{K}^{+}$to achieve a final concentration of $5 \mathrm{mM}$. Cells were exposed to $10^{-8} \mathrm{M}$ $\mathrm{ANP}_{31-67}$ or vehicle ( $\mathrm{K}^{+}$-free Ringer) for $5 \mathrm{~min}$ before and during the entire period of the uptake measurement. Each experiment was performed in the presence or absence of $1 \mathrm{mM}$ ouabain, and the uptake in the presence of ouabain was subtracted from that in the absence of ouabain. Data are expressed as ouabain-sensitive uptakes in nmol/ mg protein. In unpaired $t$ tests, $P<0.005$ at $10 \mathrm{~s}$ and $P<0.01$ at 30 $s(n=10)$.

presence of potassium $(17,18)$. As shown in Fig. 4, $\mathrm{ANP}_{(31-67)}$ (open circles) significantly reduced ${ }^{86} \mathrm{Rb}^{+}$uptake, as compared with cells incubated with vehicle (filled circles). $\mathrm{ANP}_{(31-67)}$ did not alter 30-min equilibrium uptakes (data not shown). To compare initial uptake rates, uptakes were fitted as well to a closed two-compartment model (see reference 14): $\operatorname{Ln}\left(1-U_{t} /\right.$ $\left.U_{\infty}\right)=k \mathrm{t}$ where $U_{t}$ equals the uptake at time, $t, U_{\infty}$ equals the uptake at equilibrium, and $K$ equals the initial rate constant. Correlation coefficients for these fits averaged $0.992 \pm 0.003$, indicating that the data fit this model well. Rate constants for vehicle-treated cells averaged $0.13 \pm 0.02$, and the average for cells treated with $\mathrm{ANP}_{31-67}$ averaged 0.08 $\pm 0.01(P<0.005$; paired $t$ test with $n=10$ ). Thus, $\mathrm{ANP}_{31-67}$ markedly reduced basal $\mathrm{Na} / \mathrm{K}$-ATPase activity, as indicated by $\mathrm{QO}_{2}$ under basal conditions (see Fig. 2), and partially inhibited the pump under $\mathrm{V}_{\max }$ conditions (see Figs. 3 and 4).

Because we have previously observed a similar effect on $\mathrm{Na}^{+}-\mathrm{K}^{+}$-ATPase activity by $\mathrm{PGE}_{2}$ and peptides (e.g., endothelin and IL-1) which stimulate $\mathrm{PGE}_{2}$ accumulation $(17,18 \mathrm{a})$, the role of $\mathrm{PGE}_{2}$ in $\mathrm{ANP}_{(31-67)}$ action was examined. If $\mathrm{PGE}_{2}$ mediates inhibition of $\mathrm{Na}^{+}-\mathrm{K}^{+}-\mathrm{ATPase}$ by $\mathrm{ANP}_{(31-67)}$, then we would predict that: (a) $\mathrm{ANP}_{(31-67)}$ and $\mathrm{PGE}_{2}$ should give equivalent nonadditive inhibition of $\mathrm{Na}^{+}-\mathrm{K}^{+}$-ATPase activity; $(b)$ inhibition of cyclooxygenase should blunt the inhibitory effect of $\mathrm{ANP}_{(31-67)}$; and (c) $\mathrm{ANP}_{(31-67)}$ should stimulate $\mathrm{PGE}_{2}$ production under conditions similar to those yielding inhibition of $\mathrm{Na}^{+}-\mathrm{K}^{+}$-ATPase. As shown in Fig. 5, ouabain-sensitive ${ }^{86} \mathrm{Rb}^{+}$

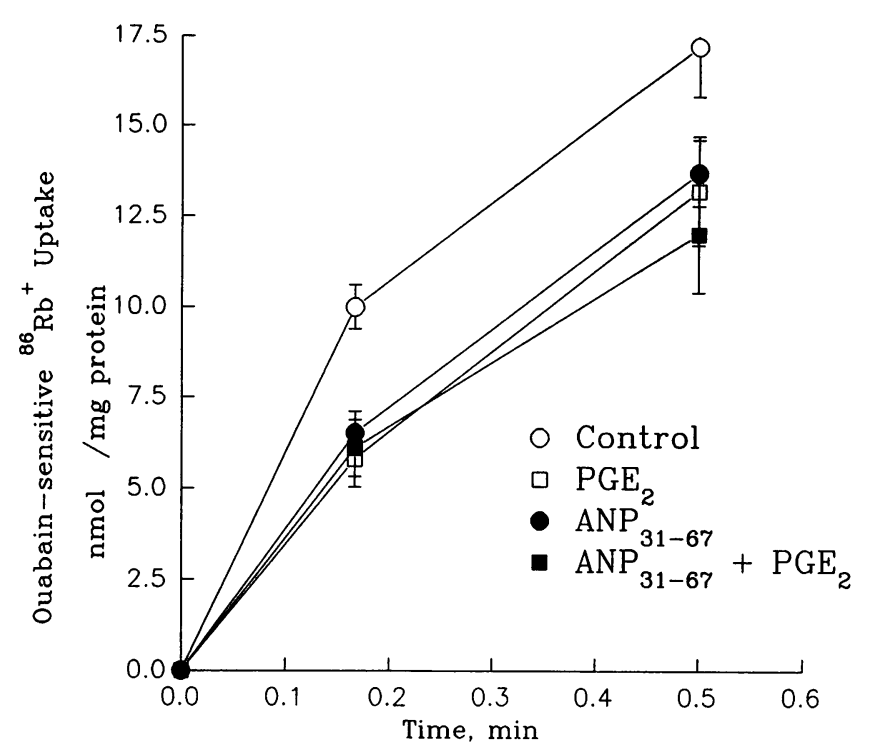

Figure 5. Effect of $\mathrm{ANP}_{31-67}, \mathrm{PGE}_{2}$, or both agents together on ouabain-sensitive ${ }^{86} \mathrm{Rb}^{+}$uptake. Uptakes were performed as described in Fig. 4. Where indicated, $\mathrm{PGE}_{2}$ was present at $10^{-6} \mathrm{M}$.

uptake was measured under four different conditions; control cells (open circles), cells exposed to $\mathrm{PGE}_{2}$ (closed squares), or $\mathrm{ANP}_{(31-67)}$ (closed circles), or both $\mathrm{PGE}_{2}$ and $\mathrm{ANP}_{(31-67)}$ (open squares). The inhibition of ouabain-sensitive ${ }^{86} \mathrm{Rb}^{+}$uptake, compared with control, was the same at both $10 \mathrm{~s}$ and $30 \mathrm{~s}$ with $\mathrm{PGE}_{2}$ alone, with $\mathrm{ANP}_{(31-67)}$ alone, or with both agents together.

In Fig. 6, the effect of ibuprofen, a cyclooxygenase inhibitor, on $\mathrm{ANP}_{(31-67)}$ inhibition of ouabain-sensitive ${ }^{86} \mathrm{Rb}^{+}$was

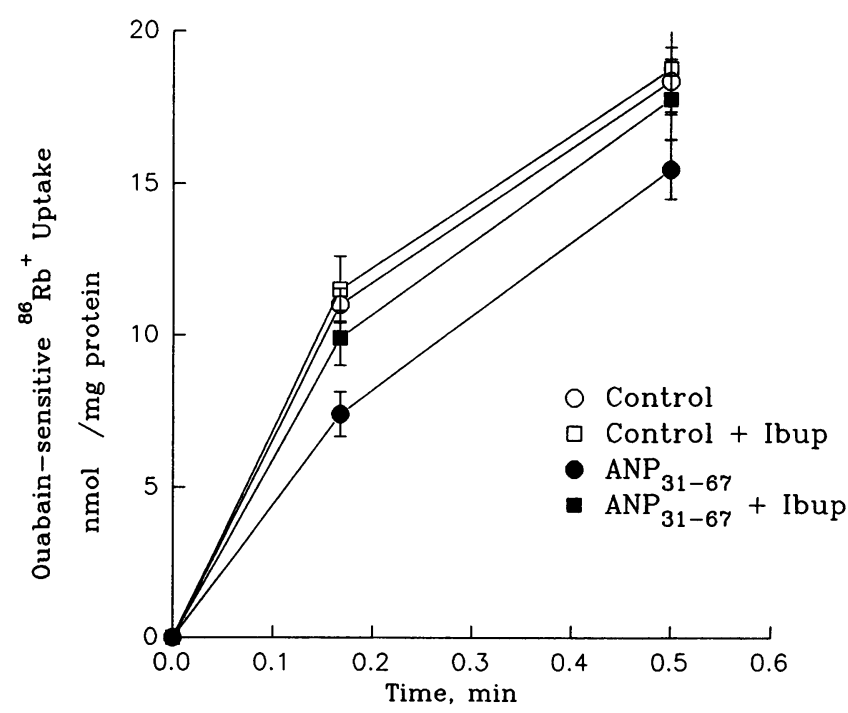

Figure 6. Effect of ibuprofen on $\mathrm{ANP}_{31-67}$ inhibition of ouabain-sensitive ${ }^{86} \mathrm{Rb}^{+}$uptake. Uptakes were performed as described in Fig. 4. Cells were preincubated in the ethanol vehicle for ibuprofen or $10^{-4}$ $\mathrm{M}$ ibuprofen for $10 \mathrm{~min}$, exposed to $\mathrm{PGE}_{2}$ or its vehicle (ethanol) for $5 \mathrm{~min}$, and the uptakes were performed. Using a paired $t$ test to compare the absolute rates of uptake with $\mathrm{ANP}_{31-67}$ in the presence or absence of ibuprofen, $P<0.001$ at $10 \mathrm{~s}$ and $P<0.005$ at $30 \mathrm{~s}(n=6$ pairs). 


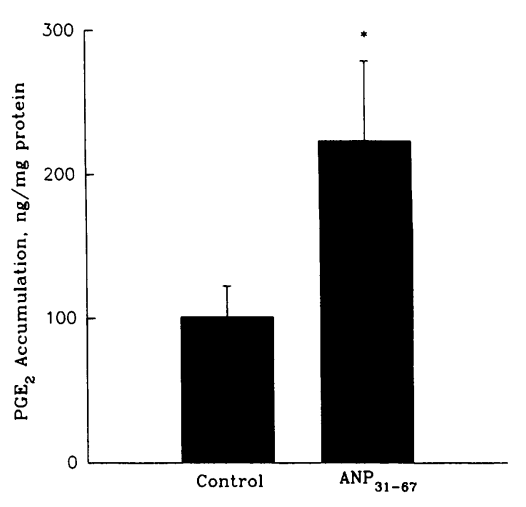

Figure 7. Effect of $\mathrm{ANP}_{31-67}$ on IMCD $\mathrm{PGE}_{2}$ production. Cells were exposed to $10^{-8}$ M ANP ${ }_{31-67}$ or its vehicle (nonbicarbonate Ringer's) for $5 \mathrm{~min}$ and $\mathrm{PGE}_{2}$ production determined. Results are expressed as nanogram accumulated per milligram cell protein. ${ }^{*} P$ $<0.05$ compared with control.

measured. Cells were exposed to ibuprofen or its vehicle (ethanol), and then treated with $\mathrm{ANP}_{31-67}$ of buffer before initiation of the uptake measurement. Pretreatment with ibuprofen markedly attenuated the inhibitory effect of $\mathrm{ANP}_{31-67}$ on $\mathrm{Na}^{+}$$\mathrm{K}^{+}$-ATPase activity.

Studies shown in Fig. 7 examine the effects of $\mathrm{ANP}_{(31-67)}$ on $\mathrm{PGE}_{2}$ production by IMCD cells. Control IMCD cells were incubated with vehicle alone, and produced $101.4 \pm 21.6 \mathrm{ng}$ $\mathrm{PGE}_{2} / \mathrm{mg}$ protein. Incubation with $\mathrm{ANP}_{(31-67)}$, however, stimulated the cells to double their production of $\mathrm{PGE}_{2}(223.6$ $\pm 55.5 \mathrm{ng} / \mathrm{mg}$ protein; $P<0.05$ compared with control). Thus $\mathrm{ANP}_{(31-67)}$ stimulates the production of $\mathrm{PGE}_{2}$ in IMCD cells.

To determine whether $\mathrm{ANP}_{(31-67)}$ might stimulate cGMP accumulation (21), IMCD cells were incubated with either $\mathrm{ANP}_{(99-126)}$ or $\mathrm{ANP}_{(31-67)}$ in the presence of IBMX, and cGMP generation was measured. Since the inhibition of $\mathrm{QO}_{2}$ effected by $\mathrm{ANP}_{31-67}$ is first apparent at 1-2 min after addition of the peptide, cGMP levels were determined after 2 min of exposure to the peptide. It was anticipated that if cGMP mediated the actions of $\mathrm{ANP}_{31-67}$, the levels of cGMP would rise before, or simultaneously with, the observed inhibition of $\mathrm{QO}_{2}$. As shown in Fig. 8, ANP $_{(99-126)}$ stimulated cGMP accumulation up to 20 -fold at maximal ( $1 \mu \mathrm{M})$ concentrations, as observed previously (13), whereas $\mathrm{ANP}_{(31-67)}$ had no discernable stimulatory effect even at maximal concentrations.

\section{Discussion}

The original descriptions of the natriuretic effect of an extract of rat atria in bioassay rats demonstrated for the first time that the heart elaborated a substance that could contribute to $\mathrm{Na}^{+}$ homeostasis (1). The structure of this atrial natriuretic factor was rapidly elucidated (4). The protein is synthesized as a prepropeptide of 151 amino acids which, after removal of the signal peptide, is stored as a 126 amino acid pro- $A N P\left(\mathrm{ANP}_{1-126}\right)$. After release of $\mathrm{ANP}_{1-126}$ from atrial cells, the final 28 amino acids from the carboxy terminal are cleaved off, forming $\mathrm{ANP}_{\text {99-126 }}$ (4-6). Because this carboxy-terminal product was readily detectable and exhibited nearly all of the actions of atrial extracts, virtually all subsequent studies focused on the actions of $\mathrm{ANP}_{(99-126)}$. However, early studies also showed that intact $\mathrm{ANP}_{(1-126)}$ exhibits biological activity (5). More recent evidence suggests that fragments of $\mathrm{ANP}_{(1-98)}$ also circulate in humans, are regulated by appropriate changes in volume status, are elevated in disease states, and have a natriuretic effect in the kidney.
Studies examining the potential role of portions of the $\mathrm{ANP}_{1-98}$ peptide used selective antisera raised against synthetic fragments of the $\mathrm{ANP}_{(1-98)}$ peptide to identify circulating forms of ANP. Itoh et al. (7) demonstrated the secretion of a $10-\mathrm{kD}$ fragment with the 3-kD ANP ${ }_{(99-126)}$, while Meleagros et al. suggested that the circulating amino portion of $\mathrm{ANP}_{1-98}$ encompassed the amino acids 1-67 (cardiodilatin) (22). Winters et al. demonstrated that antibodies that selectively recognize $\mathrm{ANP}_{31-67}$ and not other portions of $\mathrm{ANP}_{1-126}$ detected a circulating peptide in human plasma $(8,9)$. This circulating peptide coeluted with authentic synthetic $\mathrm{ANP}_{31-67}$ on reverse phase HPLC, and was shown by gel filtration to have a molecular mass of 4,000, similar to that of authentic $\mathrm{ANP}_{31-67}$ (9). They further demonstrated that, like $\mathrm{ANP}_{99-126}$, this peptide circulates at increased concentrations after HOWI, and in patients with congestive heart failure (8-10). Importantly, this peptide achieves higher plasma levels and exhibits a longer half-life than $\mathrm{ANP}_{99-126}(8-10)$. Finally, Martin et al. demonstrated that injection of synthetic $\mathrm{ANP}_{31-67}$ into rats stimulates natriuresis (11). The natriuresis was similar in magnitude to that seen with $\mathrm{ANP}_{(99-126)}$, and occurred in the absence of a detectable change in the GFR.

Thus, $\mathrm{ANP}_{31-67}$ or a nearly identical peptide circulates at levels that respond to changes in atrial pressure, is biologically active, and may play an important role in the regulation of salt balance in mammals. Furthermore, its prolonged half-life over that of $\mathrm{ANP}_{(99-126)}$ suggests that the atrial natriuretic peptide system may respond in an acute fashion via $\mathrm{ANP}_{(99-126)}$, and in a more prolonged fashion via the $\mathrm{ANP}_{(31-67)}$ moiety.

Little is known of the mechanism by which $\operatorname{ANP}_{(31-67)}$ exerts its renal actions. Our results show that unlike $\mathrm{ANP}_{(99-126)}$, which inhibits $\mathrm{Na}^{+}$entry through the amiloride-sensitive $\mathrm{Na}^{+}$ channel $(14,15), \mathrm{ANP}_{(31-67)}$ is a potent inhibitor of

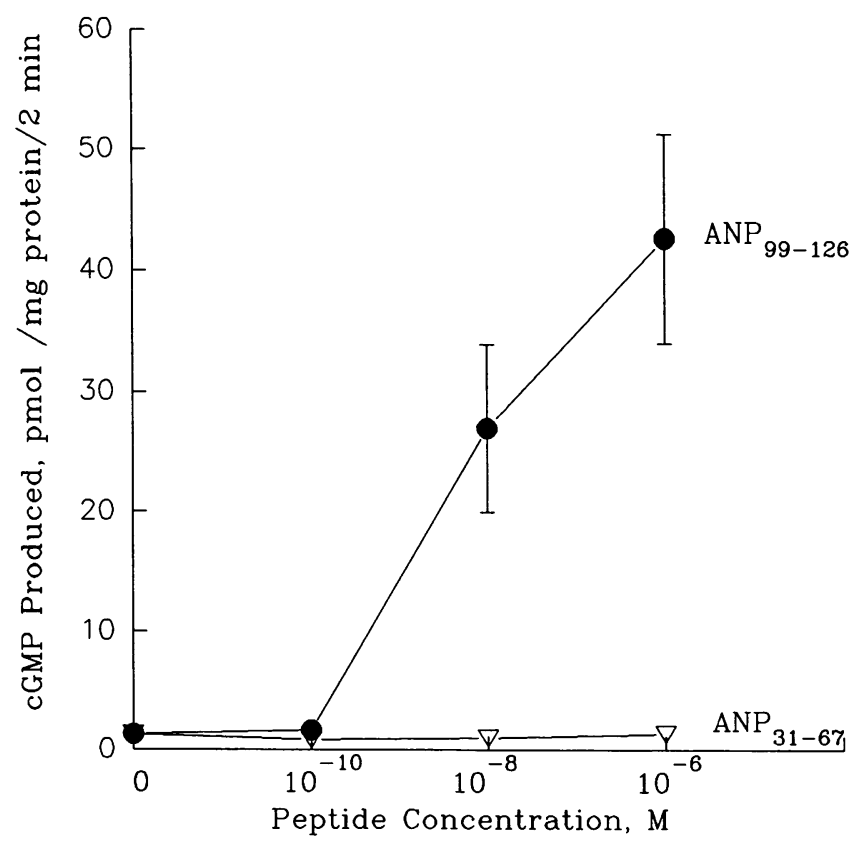

Figure 8. Effect of $\mathrm{ANP}_{31-67}$ and $\mathrm{ANP}_{99-126}$ on IMCD cGMP production. Cells were treated for $5 \mathrm{~min}$ at $37^{\circ} \mathrm{C}$ with the peptides as indicated in the presence of $10^{-4} \mathrm{M}$ isobutylmethylxanthine (IBMX) before extraction and assay of cGMP accumulation. 
$\mathrm{Na}^{+}-\mathrm{K}^{+}$-ATPase activity in IMCD cells. From the data presented in Figs. 1-4, it can be concluded that the peptide inhibits transcellular $\mathrm{Na}^{+}$transport in IMCD cells at concentrations similar to those observed in vivo. Two approaches, each designed to isolate effects on $\mathrm{Na}^{+}-\mathrm{K}^{+}$-ATPase from effects on $\mathrm{Na}^{+}$ entry, demonstrated inhibition of the pump. In the studies of $\mathrm{QO}_{2}$, amphotericin $\mathrm{B}$ was used to allow rapid $\mathrm{Na}^{+}$entry into the cells, maximally stimulating the pump $(17-19)$. The inhibitory effect of $\mathrm{ANP}_{(31-67)}$, but not of $\mathrm{ANP}_{(99-126)}$ in this setting strongly suggests that $\mathrm{ANP}_{(31-67)}$ inhibits pump activity itself. This impression was confirmed by measurements of ouabainsensitive ${ }^{86} \mathrm{Rb}^{+}$uptake. The uptake measurements were performed in cells preincubated in $\mathrm{K}^{+}$-free medium. In the absence of $\mathrm{K}^{+}$, the pump is reversibly inhibited, leading to accumulation of intracellular $\mathrm{Na}^{+}$and depletion of intracellular $\mathrm{K}^{+}$. The finding of inhibition of uptake under these conditions demonstrates that $\mathrm{ANP}_{(31-67)}$ acts on the pump itself, and does not reduce pump activity by inhibiting $\mathrm{Na}^{+}$entry pathways.

This mechanism of action distinguishes $\mathrm{ANP}_{31-67}$ from $\mathrm{ANP}_{99-126}$ because the binding of the latter to its receptor stimulates cGMP accumulation which in turn reduces $\mathrm{Na}^{+}$entry via the amiloride-sensitive cation channel $(12,14,15,23,24)$. The demonstration that $\mathrm{ANP}_{31-67}$ did not stimulate cGMP accumulation, despite concurrent inhibition of phosphodiesterase by IBMX, again favors a direct inhibition of pump activity, and prompted a search for a different intracellular mediator.

$\mathrm{PGE}_{2}$ stimulates natriuresis in the distal nephron $(25,26)$, and acute infusion of normal saline elicits an increase in renal prostaglandin excretion. Direct transport effects of $\mathrm{PGE}_{2}$, including inhibition of net $\mathrm{Na}^{+}$reabsorption, have been demonstrated in isolated cortical and medullary collecting tubules $(25,27)$. We have previously shown that $\mathrm{PGE}_{2}$ inhibits $\mathrm{Na}^{+}-$ $\mathrm{K}^{+}$-ATPase activity in IMCD cells (17). More recently, Strange has demonstrated that exposure of isolated perfused cortical collecting duct to basolateral $\mathrm{PGE}_{2}$ leads to cell swelling, an effect strikingly similar to that obtained with basolateral ouabain (28). These results indicate that $\mathrm{PGE}_{2}$ inhibits $\mathrm{Na}^{+}-\mathrm{K}^{+}$-ATPase in cortical and IMCDs.

In this regard, it is of interest that Epstein et al. have demonstrated that the natriuresis, after HOWI, is accompanied by an increase in PGE excretion (29); because of the enormous renal medullary $\mathrm{PGE}_{2}$ synthetic capacity, excretion is thought to reflect de novo medullary $\mathrm{PGE}_{2}$ synthesis. Prior treatment of subjects with the cyclooxygenase inhibitor, indomethacin, blunted both the natriuresis and PGE excretion, particularly in volume-depleted subjects. Thus, the natriuretic effect of HOWI, which is thought to involve increased venous return to the heart, atrial stretching, and release of atrial natriuretic peptides, is dependent at least in part on intact prostaglandin synthesis.

These considerations prompted us to examine the role of $\mathrm{PGE}_{2}$ in the mediation of the $\mathrm{ANP}_{(31-67)}$ response. Our data show that the inhibition of pump activity by this peptide is equivalent and nonadditive with $\mathrm{PGE}_{2}$, and is markedly attenuated by pretreatment of the IMCD cells with ibuprofen. In addition, $\mathrm{ANP}_{(31-67)}$ stimulates $\mathrm{PGE}_{2}$ production in IMCD cells under conditions similar to those used to examine transcellular $\mathrm{Na}^{+}$transport in these cells. These results provide strong evidence that $\mathrm{PGE}_{2}$ mediates the inhibitory effect of $\mathrm{ANP}_{(31-67)}$ on $\mathrm{Na}^{+}-\mathrm{K}^{+}$-ATPase activity. We have recently demonstrated a similar role for $\mathrm{PGE}_{2}$ in mediating inhibition of IMCD Na transport by IL1 and endothelin $(18,18 \mathrm{a})$; these peptides, like $\mathrm{ANP}_{31-67}$, have also been shown to stimulate natriuresis in intact animals by predominantly tubule mechanisms. These results suggest a common mechanism by which renal medullary production of $\mathrm{PGE}_{2}$ mediates the actions of several natriuretic peptides in vivo.

Thus, our data suggest that atrial peptides exert their natriuretic effects by more than one mechanism in the IMCD cell. The previously described mechanism of guanylate cyclase activation by $\mathrm{ANP}_{(99-126)}$ may be important for the acute regulation of $\mathrm{Na}^{+}$transport, while inhibition of IMCD $\mathrm{Na}^{+}-\mathrm{K}^{+}$-ATPase activity by $\mathrm{ANP}_{31-67}$ may be important in more long-term regulation of $\mathrm{Na}^{+}$balance.

\section{Acknowledgments}

We thank M. Epstein and D. L. Veseley for helpful discussions.

These studies were supported by National Institutes of Health grant RO-1 DK-35930 to B. M. Brenner and DK-43955 to M. L. Zeidel, and by Department of Veterans Affairs Merit Review Award to M. L. Zeidel. M. L. Zeidel is the recipient of a Department of Veterans Affairs Research Career Development Award.

\section{References}

1. Debold, A. J., H. B. Borrenstein, A. T. Veress, and H. Sonnenberg. 1981. A rapid and potent natriuretic response to intravenous injection of atrial myocardial extract in rats. Life Sci. 28:89-94.

2. Sonnenberg, H., W. A. Cupples, A. J. De Bold, and A. T. Veress. 1982 Intrarenal localization of the natriuretic effects of cardiac atrial extract. Can. J. Physiol. Pharmacol. 60:1149-1152.

3. Sonnenberg, H., U. Honrath, C. K. Chong, and D. R. Wilson. 1986. Atrial natriuretic factor inhibits sodium transport in medullary collecting duct. Am. J. Physiol. 250:F963-F966.

4. Brenner, B. M., B. J. Ballermann, M. E. Gunning, and M. L. Zeidel. 1990. The diverse actions of atrial natriuretic peptide. Physiol. Rev. 70:665-699.

5. Kangawa, K., A. Fukuda, and H. Matsuo. 1985. Identification of beta and gamma human atrial natriuretic polypeptides. Nature (Lond.). 313:397-400.

6. Schwartz, D., D. M. Geller, P. T. Manning, N. R. Siegel, K. F. Fok, C. E. Smith, and P. Needleman. 1985. Ser-leu-arg- arg-Atriopeptin III: The major circulating form of atrial peptide. Science (Wash. DC). 229:397-400.

7. Itoh, H., K. Nakao, M. Mukoyama, A. Sugawara, Y. Saito, N. Morii, T. Yamada, S. Shiono, H. Arai, and H. Imura. 1988. Secretion of N-terminal fragment of human atrial natriuretic polypeptide. Hypertension (Dallas). 11(Suppl. I):I-52-I-56

8. Winters, C. J., A. L. Sallman, J. Meadows, D. M. Rico, and D. L. Vesely. 1988. Two new hormones: prohormone atrial natriuretic peptides 1-30 and 3167. Biochem. Biophys. Res. Commun. 150:231-236.

9. Winters, C. J., A. L. Sallman, B. J. Baker, J. Meadows, D. M. Rico, and D. L. Vesely. 1989. The N-terminus and a $4000-\mathrm{MW}$ peptide from the midportion of the N-terminus of the atrial natriuretic factor prohormone each circulate in humans and increase in congestive heart failure. Circulation. 80:438-449.

10. Vesely, D. L., P. Norsk, C. J. Winters, D. M. Rico, A. L. Sallman, and M. Epstein. 1989. Increased release of the N-terminal and C-terminal portions of atrial natriuretic factor during immersion-induced central hypervolemia in normal humans. Proc. Soc. Exp. Biol. Med. 192:230-235.

11. Martin, D. R., J. B. Pevahouse, D. J. Trigg, D. L. Vesely, and J. E. Buerkert. 1990. Three peptides from the ANP prohormone amino terminus are natriuretic and/or kaliuretic. Am. J. Physiol. 258:F1401-F1408.

12. Zeidel, M. L. 1990. Renal actions of atrial natriuretic peptide: regulation of collecting duct sodium and water transport. Annu. Rev. Physiol. 52:747-759.

13. Zeidel, M. L., P. Silva, B. M. Brenner, and J. L. Seifter. 1987. Cyclic GMP mediates effects of atrial peptides on medullary collecting duct cells. Am. J. Physiol. 252:F551-F559.

14. Zeidel, M. L., D. Kikeri, P. Silva, M. Burrowes, and B. M. Brenner. 1988. Atrial natriuretic peptides inhibit conductive sodium uptake by rabbit inner medullary collecting duct cells. J. Clin. Invest. 82:1067-1074.

15. Light, D. B., E. M. Schwiebert, K. H. Karlson, and B. A. Stanton. 1989. Atrial natriuretic peptide inhibits a cation channel in renal inner medullary collecting duct cells. Science (Wash. DC). 243:383-385. 
16. Zeidel, M. L., J. L. Seifter, S. Lear, B. M. Brenner, and P. Silva. 1986. Atrial peptides inhibit oxygen consumption in kidney medullary collecting duct cells. Am. J. Physiol. 251:F379-F383.

17. Jabs, K., P. Silva, and M. L. Zeidel. 1989. Prostaglandin E2 inhibits $\mathrm{Na} / \mathrm{K}-\mathrm{ATP}$ ase in rabbit inner medullary collecting duct cells. Am. J. Physiol. 257:F424-F430.

18. Zeidel, M. L., H. R. Brady, B. C. Kone, S. R. Gullans, and B. M. Brenner. 1989. Endothelin, a peptide inhibitor of $\mathrm{Na} / \mathrm{K}-\mathrm{ATPase}$ in intact renal tubular epithelial cells. Am. J. Physiol. 257:C1101-C1107.

18a. Zeidel, M. L., H. R. Brady, and D. E. Kohan. 1991. Interleukin-1 inhibition of $\mathrm{Na} / \mathrm{K}-\mathrm{ATPase}$ in inner medullary collecting duct cells: role of $\mathrm{PGE}_{2} . \mathrm{Am}$. J. Physiol. 261:1013-1016.

19. Kone, B. C., D. Kikeri, M. L. Zeidel, and S. R. Gullans. 1989. Cellular pathways of potassium transport in renal inner medullary collecting duct. $\mathrm{Am}$. J. Physiol. 256:C823-C830.

21. Vesely, D. L., J. M. Bayliss, and A. L. Sallman. 1987. Human prepro atrial natriuretic factors $26-55,56-92$, and 104-123 increase renal guanylate cyclase activity. Biochem. Biophys. Res. Commun. 143:186-193.

22. Meleagros, L., J. S. R. Gibbs, M. A. Ghatei, and S. R. Bloom. 1988
Increases in plasma concentrations of cardiolatin (amino terminal pro-atrial natriuretic peptide) in cardiac failure and during recumbancy. Br. Heart J. 60:39-44.

23. Gunning, M. E., B. J. Ballermann, P. Silva, B. M. Brenner, and M. L. Zeidel. 1988. Characterization of ANP receptors in rabbit inner medullary collecting duct cells. Am. J. Physiol. 255:F324-F330.

24. Gunning, M. E., P. Silva, B. M. Brenner, and M. L. Zeidel. 1989. Characteristics of ANP-sensitive guanylate cyclase in inner medullary collecting duct cells. Am. J. Physiol. 256:F766-F775.

25. Iino, Y., and M. Imai. 1978. Effects of prostaglandins on sodium transport in isolated collecting tubules. Pfluegers Arch. Eur. J. Physiol. 373:125-132.

26. Bolger, P. M., G. M. Eisner, P. W. Ramwell, L. M. Slotkoff, and E. J. Corey, 1988. Renal actions of prostacycline. Nature (Lond.). 271:467-469.

27. Stokes, J. B., and J. P. Kokko. 1977. Inhibition of sodium transport by prostaglandin E2 across the isolated, perfused rabbit collecting tubule. J. Clin. Invest. 59:1099-1104.

28. Strange, K. 1990. Volume regulation following Na pump inhibition in CCT principal cells: apical K loss. Am. J. Physiol. 258:F732-F740.

29. Epstein, M. H., M. D. Lifschiz, D. S. Hoffman, and J. H. Stein. 1979. Relationship between renal prostaglandin $\mathrm{E}$ and renal sodium handling during water immersion in normal man. Circ. Res. 45:71-80. 